ЕЛЕКТРОНІКА

РАДІОТЕХНІКА

ЗАСОБИ ТЕЛЕКОМУНІКАЦІЙ

ELECTRONICS

RADIO ENGINEERING

TELECOMMUNICATION FACILITIES

UDC 621.391:517.951

Yu.K. Filipsky, DEng, Prof.,

A.R. Agadzhanyan, $\mathrm{PhD}$,

I.V. Svyryd, Master,

Odessa National Polytechnic University

\title{
APPLICATION OF TIME-FREQUENCY SPECTRAL ANALYSIS METHODS
}

Introduction. The spectral analysis through Fourier transform obtained an extensive use, especially when switching to discrete and fast Fourier transforms.

But this analytical method has some limitations, the main one consisting in requirement of signals stationary characteristic with the same range during whole time period from zero to infinity. Only at that precondition the spectrum frequency components are determined quite accurately, i.e. the signal spectral density is represented as delta functions with harmonics zero width.

The spectral components do loss their delta functions characteristic $\delta(\omega-n \Omega)$ even while the stationary signal existing not infinitely but during a given lifespan $0 \ldots T_{c}$. At that the signal spectral density is extended with multiplier $\gamma(j \omega)$, and the spectral lines obtain their final width $2 \Delta f=2 / T_{c}$.

Literature review. Generic feature of modern analytical methods for non-stationary signals and dynamic modes consists in the use of two-dimensional characteristics that allow analysis implemented not by ordinary planes of time or frequency, but within a complex time-frequency plane that extends the analysis possibilities in practical applications [1...4].

It is known that the Fourier transform weakness is manifested in lack of response to local changes in the signal, and impossibility to identify this signal by its frequency spectrum [4]. More convenient is to use time-frequency wavelet transform that can reflect local changes in the signal and being suitable for complex non-stationary processes analysis. Unlike the Fourier transform, the time-frequency wavelet-method allows to separate time and frequency components of non-stationary signals [2].

The real signals are continuously changing, i.e. their stationary characteristics disappears. For that consideration taking into account the time-frequency analysis methods are developed [1...4].

DOI 10.15276/opu.1.45.2015.23

(C) Yu.K. Filipsky, A.R. Agadzhanyan, I.V. Svyryd, 2015

ЕЛЕКТРОНІКА. РАДІОТЕХНІКА. ЗАСОБИ ТЕЛЕКОМУНІКАЦІЙ 
The need to implement the time-frequency analysis methods is illustrated by the following example. Let a signal has two discrete components. If they are present at all times, in the frequency plane the signal has two harmonics. But the same spectrum is appropriate to a signal whose frequencies are successively mutually replaced $[3,4]$. In such a case, we observe a time-frequency spectrum that depends now on two parameters: frequency and time. Classical Fourier transform does not allow identification of these signals to distinguish them.

Thus, there arises a need for transformation that has flexible time-frequency window able to narrow automatically when signal high areas considering and to expand when low areas study.

Aim of Research consists in comparative analysis using time-frequency methods of signals (circuits) spectral analysis to provide reasonable guidelines as to those methods further use.

Main Body. For further development of signals and circuits spectral analysis methods especially in a dynamic state, the transition to windowed Fourier transform (WFT) is made [3]. There exist numerous windows which must satisfy the requirement of window width overlapping the signal stationary area across which its parameters remain unchanged.

A good example of such a window represents the Gaussian function

$$
V(t)=e^{-\frac{a t^{2}}{2}},
$$

where $a-$ parameter assigning the window width;

$t$ - time.

Then the signal $x(t)$ depends upon two parameters

$$
S(j \omega, t)=\int_{0}^{t} x(t) \cdot \stackrel{*}{V}(t-\tau) \cdot e^{-j \omega t} d t
$$

where $x(t)$ - given signal;

$\tau$ - time of function (1) shift along the time axis from 0 to signal end $T_{c}$;

$V(t)$ - window function;

$\omega$ - angular velocity;

* - mark identifying the complex mating.

The WFT disadvantage is that the window width remains the same at all signal spectrum harmonics frequencies. In such a way the time-frequency transformation gets assigned time intervals and the spectrum width. Based on the Heisenberg uncertainty principle [3] these values must be reciprocally proportional. Moreover, with window introduction there appears dynamics in determining the signal, i.e. a signal amplitude growth time characteristic. On the basis of calculations (2) obtained are twodimensional time-frequency functions for different values of $a$ parameter at the above considered example of harmonic signal having two frequencies. Fig. 1 shows an image of signal with a narrow Gaussian window $(a=0,001)$, and Fig. 2 represents a wide window picture $(a=0,0001)$.

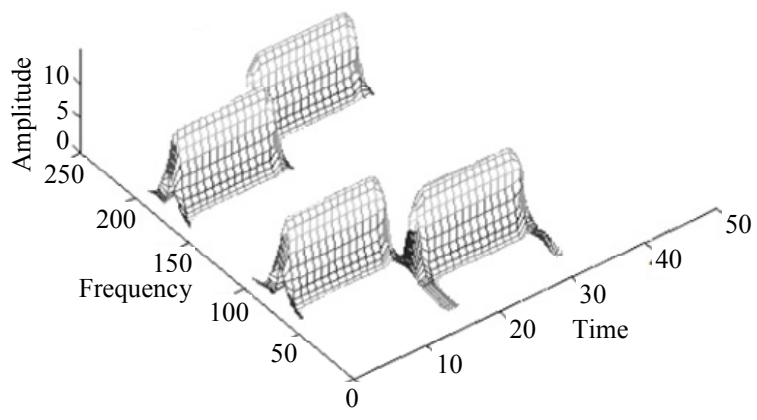

Fig. 1. Two-parametric spectrum at narrow window $(a=0,001)$

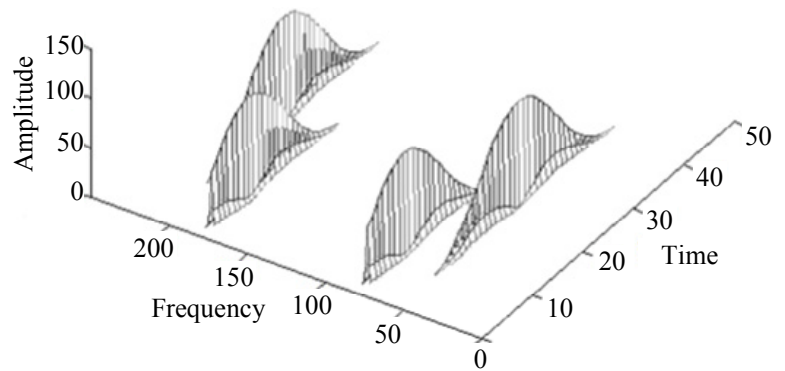

Fig. 2. Two-parametric spectrum at wide window $(a=0,0001)$ 
From Fig. 2 we do clearly observe a gradual increase in amplitude, i.e. the transition process. At that the frequency evaluation becomes more accurate, but the time intervals are not clearly defined. Fig. 1, on the contrary, shows the fast increase in amplitude, but the frequency band does significantly expand. At the same time, clearly defined are the time intervals.

Another method of time-frequency analysis is this one of dynamic coefficient of transition $K(j \omega, t)$ (DCT) [1], using Fourier transform technique applied to the pulse response with variable upper limit

$$
K(j \omega, t)=\int_{0}^{t} h(t) \cdot e^{-j \omega t} d t,
$$

where $h(t)$ - linear circuit impulse characteristic.

It is advisable to use DCT when harmonic oscillations amplitude bouncing.

Fig. 3 shows the envelope fluctuations time-dependencies when the second order circuits analysis. The parameter $\xi$ does mean the signal deviation from the resonant frequency range.

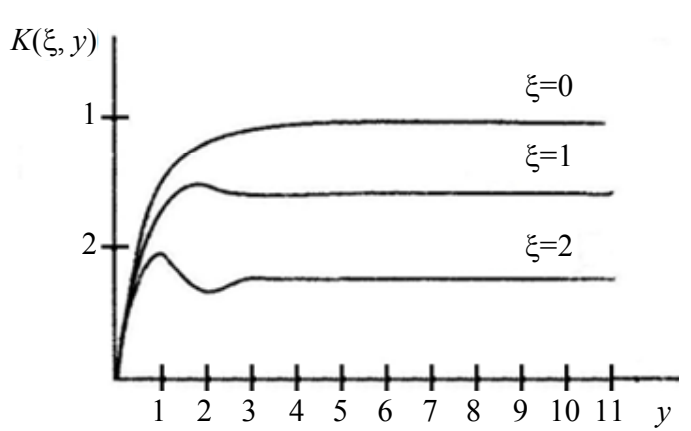

Fig. 3. Envelope time parameters at the second order circuit output ( $\xi$ - frequency disagreement)

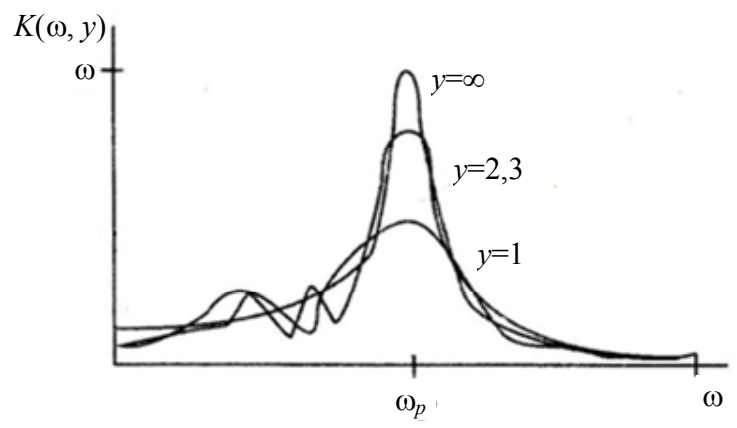

Fig. 4. Second order circuit frequency parameters $\left(\omega_{p}\right.$ - resonance frequency)

Fig. 4 represents the circuit resonance parameters family obtained over time at various parameter metering scheduled instances.

Both Fig. 3 and 4 refer to a fixed time value

$$
y=\frac{t}{\tau_{c}}
$$

where $\tau_{c}$ - circuit time constant.

Further developing the DCT we can analyze fluctuations at phase and frequency alternations.

The second form of DCT method represents the Turbovich method [1], serving in basis to analyze the linear frequency modulation (LFM)

$$
K_{D}(j \omega)=\int_{0}^{\infty} h(\tau) \cdot e^{-j\left(\omega \tau-\frac{1}{2} \beta \tau^{2}\right)} d t=K(j \omega)-\frac{1}{2} \cdot j \beta K^{\mathrm{II}}(j \omega)-\frac{1}{8} \cdot \beta^{2} K^{\mathrm{IV}}(j \omega),
$$

where $K(j \omega)=\int_{0}^{\infty} h(\tau) \cdot e^{-j \omega \tau} d \tau$ - circuit transition stationary coefficient;

$K^{\mathrm{II}}(j \omega), K^{\mathrm{IV}}(j \omega)$ - respectively its $2^{\text {nd }}$ and $4^{\text {th }}$ derivatives by frequency;

$\beta$ - rate of LFM signal frequency readjustments.

Fig. 5 represents the family of second order circuit dynamic resonance parameters at various rate of LFM signal frequency readjustments $\beta=2 \Delta \omega / \tau_{i}$, where $2 \Delta \omega$ - width of frequency readjustment at impulse of $\tau_{i}$ duration. The resonance curve 1 refers to the stationary mode (frequency without 


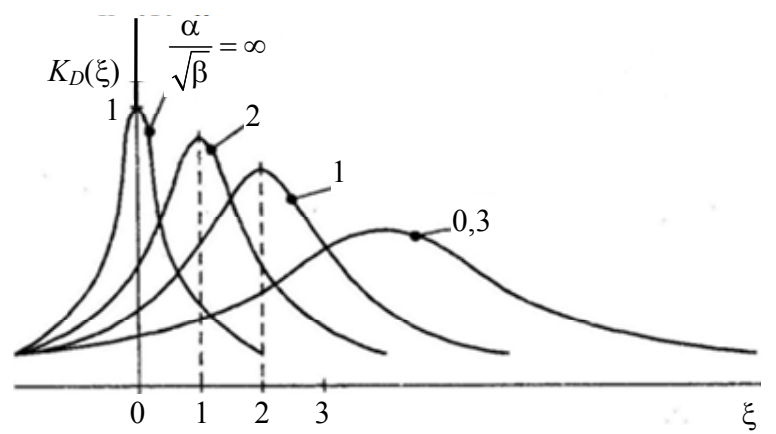

Fig. 5. Circuit frequency parameter dependency onto frequency readjustment with various values of $\alpha / \sqrt{\beta}$ according to $\infty ; 2 ; 1 ; 0,3: \alpha$-oscillations damping, $\beta$ - frequency readjustment velocity, $K_{D}-$ dynamic characteristic changes). Readjustment velocity increased the curves are shifted to the readjustment side, expanding, and their height decreases.

Results. The most developed from among frequency-time analysis methods is this one of wavelet transform where due to scaling (window width value introduced) $a$ the WFT imperfections are eliminated. At that not only the window shifting for $\tau$ interval takes place, but also modified is the frequency-dependent scale at the expense of $a$ coefficient. The wavelet transform spectrum is

$$
S(\tau, a)=\frac{1}{\sqrt{a}} \int_{0}^{T} x(t) \cdot \stackrel{*}{V}\left(\frac{t-\tau}{a}\right) d t,
$$

where $\stackrel{*}{V}\left(\frac{t-\tau}{a}\right)$ is called the parent wavelet.

There exist numerous parent wavelets [2], and their selection depends onto a specific given problem to resolve.

Conclusions. Thus, presently the radio signals and circuits analysis when a dynamic state may can be implemented using different methods. The method selection depends on what parameters are required to be analyzed: frequency or time. In stationary signals analysis more convenient is the method of dynamic coefficient of transfer. Analysing non-stationary signals, in a narrow frequency range the preference should be given to the windowed Fourier transform, and when wide frequency range, to the wavelet transformations.

\section{Література}

1. Boashash, B. Time frequency signal analysis and processing: A comprehensive reference / B. Boashash. Amsterdam; Boston: Elsevier, 2003. - 770 p.

2. Goswami, J.C. Fundamentals of wavelets: theory, algorithms, and applications / J.C. Goswami, A.K. Chan. - $2^{\text {nd }}$ Ed. - Hoboken, N.J.: Wiley, 2011. - 359 p.

3. Филипский, Ю.К. Анализ динамических характеристик аналоговых и цифровых фильтров произвольных порядков / Ю.К. Филипский, С.В. Семенюк // Пр. Одес. політехн. ун-ту. — 2012. № 1(38). - С. $163-169$.

4. Павлов, А.Н., Филатова, А.Е., Храмов, А.Е. Частотно-временной анализ нестационарных процессов: концепции вейвлетов и эмпирических мод / А.Н. Павлов, А.Е. Филатова, А.Е. Храмов // Изв. ВУЗов. Прикладная нелинейная динамика. - 2011. — Т. 19, № 2. - С. 141 - 157.

\section{References}

1. Boashash, B. (2003). Time Frequency Signal Analysis and Processing: A Comprehensive Reference. Amsterdam; Boston: Elsevier.

2. Goswami, J.C. and Chan, A.K. (2011). Fundamentals of Wavelets: Theory, Algorithms, and Applications ( $2^{\text {nd }}$ Ed.). Hoboken, N.J.: Wiley.

3. Filipsky, Yu.K. and Semenyuk, S.V. (2012). Analysis of the dynamic characteristics of analog and digital filters of arbitrary orders. Odes 'kyi Politechnichnyi Universytet. Pratsi, 1, 163-0169.

4. Pavlov, A.N., Filatova, A.E. and Hramov, A.E. (2011). Time-frequency analysis of nonstationary processes: Concepts of wavelets and empirical modes. Izvestiya VUZ. Applied Nonlinear Dynamics, 19(2), 141-157.

\section{AHOTАЦІЯ / АННОТАЦИЯ / ABSTRACT}

Ю.К. Філіпський, А.P. Агаджанян, I.B. Свирид. Застосування частотно-часових методів спектрального аналізу сигналів. Обгрунтовано обмеженість застосування класичного аналізу спектрів нестаціонарних сигналів за до- 
помогою перетворення Фур'є. Показано, що перетворення Фур'є має переваги при аналізі періодичних сигналів та обмеження при використанні їх для нестаціонарних сигналів. Проведено порівняння частотно-часових методів аналізу сигналів і кіл в динамічному стані. Наведено приклади застосування віконного перетворення Фур'є. Розглянуто метод динамічного коефіцієнта передачі для розрахунку частотно-часових параметрів кіл другого порядку. Сформульовано переваги використання вейвлет-перетворень для аналізу нестаціонарних сигналів.

Ключові слова: перетворення Фур'є, віконне перетворення, вейвлет-перетворення, динамічний режим, двовимірні характеристики кіл.

Ю.К. Филипский, А.Р. Агаджсанян, И.В. Свирид. Применение частотно-временных методов спектрального анализа сигналов. Обоснована ограниченность применения классического анализа спектров нестационарных сигналов с помощью преобразования Фурье. Показано, что преобразование Фурье имеет преимущества при анализе периодических сигналов и ограничения при их использовании для нестационарных сигналов. Проведено сравнение частотно-временных методов анализа сигналов и цепей в динамическом состоянии. Приведены примеры использования оконного преобразования Фурье. Рассмотрен метод динамического коэффициента передачи для расчета частотно-временных параметров цепей второго порядка. Сформулированы преимущества использования вейвлетпреоразований для анализа нестационарных сигналов.

Ключевые слова: преобразование Фурье, оконное преобразование, вейвлет-преобразование, динамический режим, двухмерные характеристики цепей.

Yu.K. Filipsky, A.R. Agadzhanyan, I.V. Svyryd. Application of time-frequency spectral analysis methods. In this article the limited application of the non-stationary signals spectra classical analysis using the Fourier transform is substantiated. It is shown that Fourier transform has benefits at periodic signals analysis and limitations when non-stationary signals processing. Authors compared various time-frequency methods of analysis used at signals and circuits in dynamic state. The examples of Fourier window transform application are considered. The dynamic transmission coefficient method for second order circuits time-frequency parameters calculation is studied. The advantages of wavelet transforms application at nonstationary signals analysis are stated.

Keywords: Fourier transform, window transform, wavelet transform, dynamic mode, 2D characteristics of circuits.

Received November 19, 2014 